\title{
Teaching NeuroImages: Cerebral liposuction
}

Kevin T. Gobeske, MD, PhD, MPH, Simon Maltais, MD, PhD, Harry J. Cloft, MD, PhD, and

Eelco F.M. Wijdicks, MD, PhD

Neurology ${ }^{\circledR}$ 2018;91:e692-e693. doi:10.1212/WNL.0000000000005999

A 61-year-old woman showed left hemiplegia and neglect while recovering 6 hours after aortic valve repair. CT showed a hypodense middle cerebral artery segment. CT angiography and CT perfusion (CTP) revealed a carotid terminus occlusion and a large penumbra around a small ischemic core. This prompted cerebral angiography, and embolectomy by Sofia catheter aspiration removed a $1.5-\mathrm{cm}$ piece of adipose tissue, presumably pericardial fat introduced during aortotomy (figure). The neglect, hemianopia, and hemiparesis improved thereafter. This demonstrates a successful fat embolus aspiration to treat stroke after cardiac surgery, and which should be considered if deficits are recognized early and CTP shows significant salvageable tissue. $^{1,2}$

\section{Author contributions}

Kevin Gobeske: study concept and design, acquisition of data, analysis, interpretation, and writing. Simon Maltais: acquisition of data, analysis and interpretation. Harry Cloft: acquisition of data. Eelco Wijdicks: study concept and design, acquisition of data, analysis, interpretation, and writing.

\section{Study funding}

No targeted funding reported.

\section{Disclosure}

The authors report no disclosures relevant to the manuscript. Go to Neurology.org/ $\mathrm{N}$ for full disclosures.

\section{References}

1. Lee TC, Bartlett ES, Fox AJ, Symons SP. The hypodense artery sign. AJNR Am J Neuroradiol 2005;26:2027-2029.

2. Abend NS, Levine JM. Hypodense middle cerebral artery with fat embolus. Neurocrit Care 2007;6:147-148.
Correspondence

Dr. Gobeske

Gobeske.Kevin@mayo.edu

\section{MORE ONLINE}

$\rightarrow$ Teaching slides

links.lww.com/WNL/

A629 
Figure Fat embolus aspiration to correct an acute right middle cerebral artery stroke after cardiac surgery
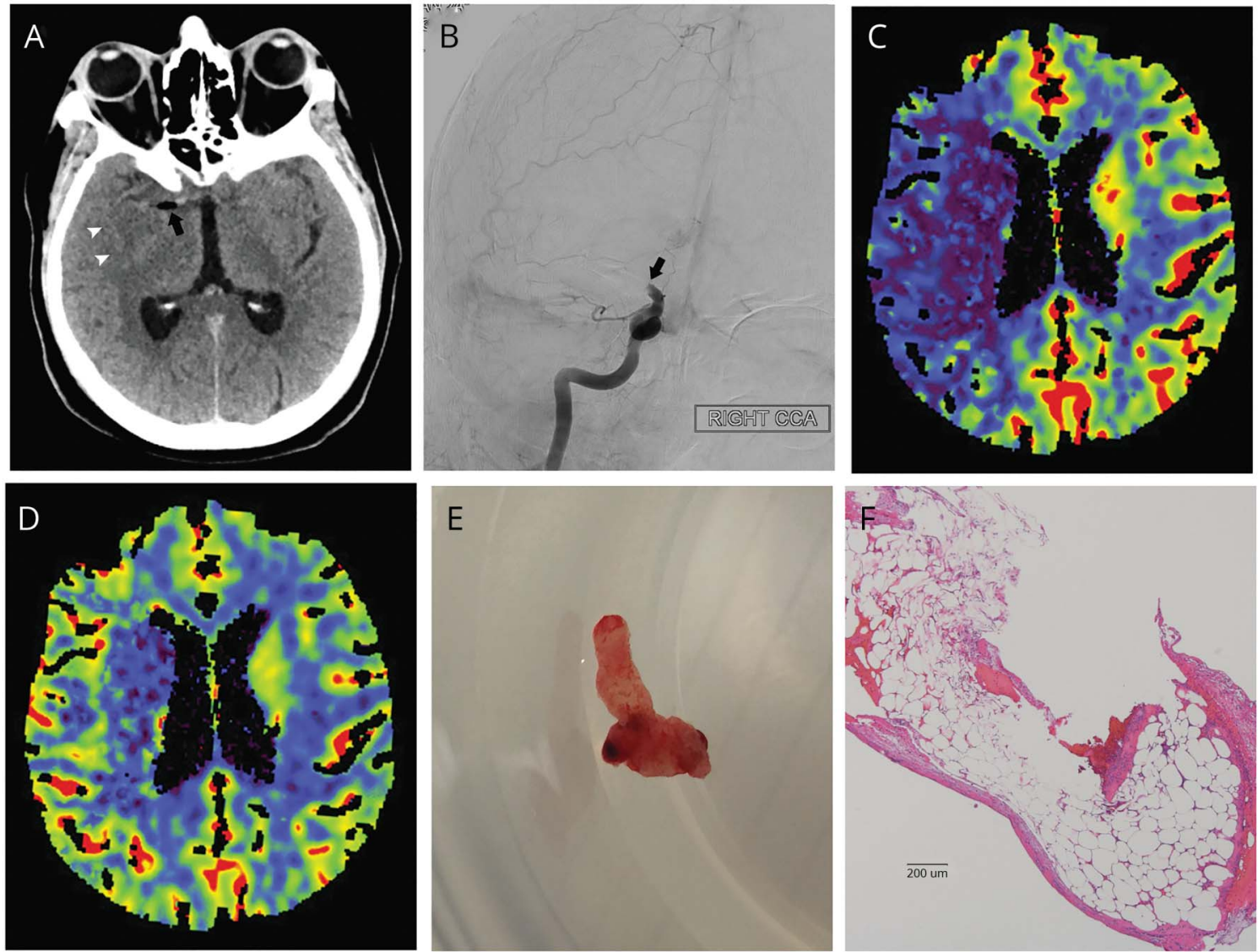

(A) CT with hypodense middle cerebral artery (arrow) and limited early ischemia (arrowheads). (B) Cerebral angiogram with ICA occlusion (arrow). (C) CT perfusion (CTP) blood flow scan shows large ischemic penumbra. (D) CTP blood volume scan shows small ischemic core. (E) Embolectomy gross pathology and (F) 40x hematoxylin \& eosin stain photomicrograph demonstrate adipose tissue. 


\title{
Neurology
}

\author{
Teaching NeuroImages: Cerebral liposuction \\ Kevin T. Gobeske, Simon Maltais, Harry J. Cloft, et al. \\ Neurology 2018;91;e692-e693 \\ DOI 10.1212/WNL.0000000000005999
}

This information is current as of August 13, 2018

\section{Updated Information \& Services}

\section{References}

Subspecialty Collections

Permissions \& Licensing

Reprints including high resolution figures, can be found at: http://n.neurology.org/content/91/7/e692.full

This article cites 2 articles, 0 of which you can access for free at: http://n.neurology.org/content/91/7/e692.full\#ref-list-1

This article, along with others on similar topics, appears in the following collection(s):

All Imaging

http://n.neurology.org/cgi/collection/all_imaging

Critical care

http://n.neurology.org/cgi/collection/critical_care

CT

http://n.neurology.org/cgi/collection/ct

Embolism

http://n.neurology.org/cgi/collection/embolism

Infarction

http://n.neurology.org/cgi/collection/infarction

Information about reproducing this article in parts (figures,tables) or in its entirety can be found online at:

http://www.neurology.org/about/about_the_journal\#permissions

Information about ordering reprints can be found online:

http://n.neurology.org/subscribers/advertise

Neurology ${ }^{\circledR}$ is the official journal of the American Academy of Neurology. Published continuously since 1951, it is now a weekly with 48 issues per year. Copyright (O) 2018 American Academy of Neurology. All rights reserved. Print ISSN: 0028-3878. Online ISSN: 1526-632X.

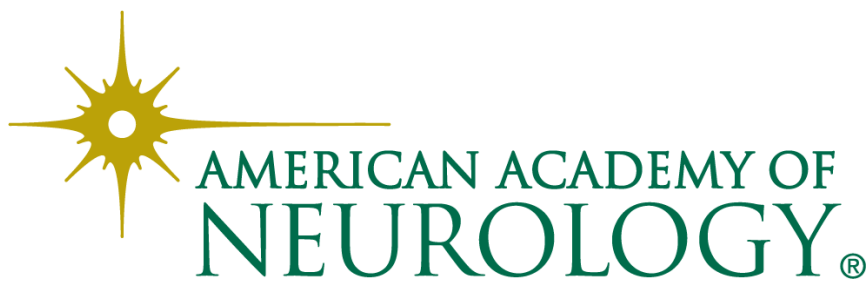

